\title{
Intraneuronal Delivery of Protein Kinase C Pseudosubstrate Leads to Growth Cone Collapse
}

\author{
Laurent Théodore, ${ }^{1, a}$ Daniele Derossi, ${ }^{1}$ Gérard Chassaing, ${ }^{2}$ Béatrice Llirbat, ${ }^{3}$ Miroslav Kubes, ${ }^{4}$ Pascale \\ Jordan, ${ }^{1}$ Hervé Chneiweiss, ${ }^{4}$ Pierre Godement, ${ }^{3}$ and Alain Prochiantz ${ }^{1}$ \\ 'Développement et Évolution du Système Nerveux, URA 1414, Centre National de la Recherche Scientifique, Ecole \\ Normale Supérieure, 75230 Paris Cedex 05, ${ }^{2}$ Chimie Organique et Biologique, URA 493, Centre National de la \\ Recherche Scientifique, Université Pierre et Marie Curie, 75005 Paris, ${ }^{3}$ Institut Alfred Fessard, UPR 2212, Centre \\ National de la Recherche Scientifique, 91198 Gif sur Yvette, and ${ }^{4}$ U114, Institut National de Santé et de la \\ Recherche Médicale, Chaire de Neuropharmacologie, Collège de France, 75231 Paris Cedex 05, France
}

\begin{abstract}
Axonal navigation during development requires that cues present in the extracelllar environment be capable of modifying the structure of the cone in a dynamic way. Protein kinase $C$ (PKC) has long been suspected to be one of the multiple molecular relays present in the terminal structure of the developing axon and involved in the transduction of extracellular signals. The latter proposal is, however, based on the use of drugs or of protocols leading to pleiotropic and often nonspecific effects. In the present study, we have taken advantage of the discovery of a peptide capable of translocating across biological membranes and to accumulate in the cytoplasm and nucleus of cells in culture, to internalize a highly specific peptidic inhibitor of PKC. We demonstrate that linking the two peptides (vector and PKC inhibitor) allows the internalization of the latter in live cells, specifically inhibits PKC and provokes a rapid modification of growth cone morphology. This set of data thus establishes that a peptidic inhibitor of PKC activity, once internalized, provokes a change in growth cone morphology, reminiscent of the collapse phenotype. In addition, the present study describes a new efficient and harmless way to introduce pharmacologically active substances in neural cells in culture.
\end{abstract}

[Key words: neurons, growth cones, cultures, protein kinase $C$, motility, collapse]

During neurite elongation, growth cones interact with several molecules present in their environment. Such intcractions require the presence of specific receptors capable of transducing extracellular molecular signals within the cells. In addition to positive signals (Tessier-Lavigne and Plazcek, 1991; Tessier-Lavigne et al., 1994), growth cone navigation also implies negative re-

\footnotetext{
Received Feb. 14. 1995: revised June 12, 1995; accepted June 2,3, 1995.

This study was supported by Centre National de la Recherche Scientifique. Ecole Normale Supérieure, SANOFI-Recherche and European Community (BIO2.CT93-0012) L Thédore and D. Derossi are fellows from Agence Nationale de la Recherche sur le SIDA and Association Française contre les My opathies. respectively. We thank A. Brunissen for peptide synthesis. G. Levesque for the videomicroscopy piloting program, and Dr. J.-M. Herbert (SANOFI-Recherche) for PKC activity measurements.

Correspondence should be addressed to Alain Prochiantz, URA 1414, Ecole Normale Supérieure, 46 Rue d'Ulm, 75005 Paris, France.

Present address: Laboratoire d`Embryologie Moléculaire et Expérimentale Université Paris XI, Bâtiment 445, 91405 Orsay Cedex. France.

Copyright (O 1995 Society for Neuroscience $0270-6474 / 95 / 157158-10 \$ 05.00 / 0$
}

sponses to extracellular cues (Bentley and O'Connor, 1994; Kaprielian and Patterson, 1994). Repulsive behaviors, arrest and/or collapse, have been observed in several models, leading to the characterization of extracellular and trans-membrane proteins that provoke growth cone collapse (Tessier-Lavigne, 1994).

Molecules, mediating positive and negative effects, probably act in concert with extracellular matrix components (see Letourneau et al., 1994, for review) and the combined effects are transduced within the growth cone. Although the exact transducing mechanisms are not known they are likely to involve multiple transmembrane receptors and second messenger pathways.

Several data suggest that protein kinase C (PKC), a family of serine-threonine kinases activated by phorbol ester, participate in the regulation of growth cone morphology and motility. The evidence, however, remains circumstantial, since it is based on the presence of PKC isoenzymes within growth cones (Campenot et al., 1994), on desensitization protocols, and on the use of lipophilic PKCs antagonists such as staurosporine and $\mathrm{H7}$ (Smalheiser, 1993; Doherty et al., 1994; Qian et al., 1994). These protocols are very indicative but suffer from the lack of specificity of the drugs (Rasouly et al., 1992; Jalava et al., 1993) and of unknown pathways triggered by long term treatment with phorbol ester.

PKC is a family of isozymes functionally sub-divided into three classes: $\mathrm{CPKC}(\alpha, \beta \mathrm{I}, \beta \mathrm{II}, \gamma)$ are $\mathrm{Ca}^{2} /$ diacylglycerol (DAG)/phosphatidyl-serine (PS) sensitive, $\operatorname{nPKC}(\delta, \epsilon, \eta, \theta)$ are only activated by the DAG/PS pathway and not by $\mathrm{Ca}^{2++}$, and aPKC $(s, \lambda)$ are the least characterized and not activated by $\mathrm{Ca}^{2+}$ nor DAG (for review see Tanaka and Nishizuka, 1994; Azzi ct al., 1992; Dekker and Parker, 1994). An N-terminus domain $\left[\mathrm{PKC}_{19-30}\right]$ corresponding to a pseudosubstrate sequence is common to all known PKC isozymes (Barja et al., 1994). Under resting conditions, this domain occupies the catalytic site of the enzyme, thereby acting as a natural inhibitor.

Several strategies have thus been developed to internalize the PKC pseudosubstrate peptide (House and Kemp, 1990; Kemp, 1991). These strategies require either membrane perturbation (addition of lipids, permeabilization) or intracellular injection (O’Brian et al., 1990; Eichholtz et al., 1993; Ward and O'Brian. 1993; Hvalby et al., 1994).

The goal of the present study was to develop a new protocol to introduce the pseudosubstrate peptide into neurons in culture 
and to study the effects of specific PKC inhibition on growth cone behavior. The internalization protocol is based on the property of the third helix of the homeodomain of Antennapedia to translocate across biological membranes (Derossi et al., 1994). We show that PKC pseudosubstrate linked to the peptide vector is internalized by live neurons, leading to specific inhibition of PKC activity and to a rapid modification of growth cone morphology.

\section{Materials and Methods}

Peptide synthesis. Peptide synthesis was carried out at a $0.1 \mathrm{mmol}$ scale (ABI model 431A synthesizer) starting from a 4-methylbenzhydrylamine (MBHA) resin. All $\mathrm{N}-\alpha$-ter-butyloxycarbonyl ( $\mathrm{N}-\alpha$-Boc) amino acids, in 10-fold excess, were assembled using dicyclohexylcarbodiimide (DCC) and 1-hydroxybenzotiazole (HOBt) as coupling agents. BocCys-(NPyS)OH was coupled directly to the peptide as the last (N-ter) amino acid. Peptides were cleaved from the resin by anhydrous fluorhydric acid (HF) and purified by preparative reverse phase HPLC (Applied Biosystems), using a $10 \times 250 \mathrm{~nm}$ Brownlee column (Aquapore Octyl, $300 \AA$ pore size) and acetonitrile gradients in aqueous $0.1 \%$ TFA (trifluoracetic acid). The purity of collected fractions was established by analytical isocratic separation (HPLC, Waters Associate) on lichrosphere $10 \mathrm{RP}-8$ columns (Mcrck) and in $0.25 \mathrm{M}$ triethylammonium phosphate pH 3.0 (buffer A) and acetonitrile. Peptide molecular weights were determined by electrospray ionization mass spectrometry in the laboratory of Dr. J. C. Tabet (Université P. et M. Curie, Paris).

Biotinylation of the PKCi peptide was performed using NHS-biotin (Pierce reagent). Free NHS-biotin was deactivated by incubation with $100 \mathrm{~mm}$ glycine for $2 \mathrm{hr}$ at $4^{\circ} \mathrm{C}$. Uncoupled deactivated pAntp ${ }_{43-58}$ and biotinylated-PKCi peptides used in control experiments were treated with a $10 \times$ molar ratio of cysteine in order to reduce the $\mathrm{N}$-terminal NPyS-cysteinyl residue of both peptides.

Coupling reaction. The pAntp t3-58 peptide for use as a vector was dissolved in deionized and degased water and treated with an equimolar ratio of tris-(2-carboxyethyl)phosphine,hydrochloride (TCEP, Molecular Probes) in order to generate a free thiol group. An equimolar ratio of NPyS-PKCi was added and the mixture was incubated at $37^{\circ} \mathrm{C}$ for $1 \mathrm{hr}$.

The yield of the reaction, estimated by SDS-PAGE followed by Coomasie staining, was routinely above $50 \%$. The coupled product (VPKCi) was further purified by HPLC on a $10 \times 250 \mathrm{~nm}$ Brownlee column (Aquapore Octyl, $300 \AA$ pore size) and lyophylized.

Cell culture. Cortical neurons from E16 rat fetuses were prepared and cultured as previously described (Lafont et al., 1993). Briefly, dissociated cells were plated onto D,L-polyornithine $(1.5 \mu \mathrm{g} / \mathrm{ml})$ coated plastic dishes at a density of $10^{4}$ cells per well in 24 multiwell plates (morphometric analysis) or of $10^{5}$ cells per well in 96 well microtitration dishes (ELISA). Astrocytes were prepared as described in Lafont et al. (1992). To visualize the internalized peptides, neurons were grown for $24 \mathrm{hr}$ and incubated for $1 \mathrm{hr}$ at $37^{\circ} \mathrm{C}$ with the peptides prediluted in $100 \mu \mathrm{l}$ of culture medium, washed twice in phosphate buffer (PBS), once in PBS plus $500 \mathrm{~mm} \mathrm{NaCl}$, rinsed in PBS, and fixed in EtOH acetic acid $\left(9: 1\right.$, by volume) for $5 \mathrm{~min}$ at $-20^{\circ} \mathrm{C}$. Biotin was revealed using FITC-streptavidin complex (Amersham) diluted 100-fold in PBS plus $0.1 \%$ Tween 20 . For immunocytochemistry, the cells were fixed ( $1 \mathrm{hr}$ at room temperature) with paraformaldehyde (4\% in PBS), rinsed

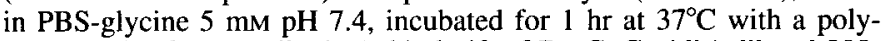
clonal anti-NCAM antibody (a kind gift of Dr. C. Goridis) diluted 200fold in PBS, washed several times and further incubated with peroxydase-linked anti-rabbit IgGs (Amersham) for $1 \mathrm{hr}$ at $37^{\circ} \mathrm{C}$. After several washes, peroxydase was revealed with diaminobenzydine $(0.2 \mathrm{mg} / \mathrm{ml}$, Sigma) and $\mathrm{H}_{2} \mathrm{O}_{2}(0.03 \%$ ) in Tris $\mathrm{HCl} 50 \mathrm{~mm}, \mathrm{pH} 7.8$. The reaction was stopped after $5 \mathrm{~min}$ by several rinses in water.

Cell viability. Cell survival was assayed by the capacity of live cells to convert soluble MTT [3-(4,5-dimethylthiazol-2-yl)-2,5-diphenyl tetrazolium bromide] into an insoluble dark-bluc formazan reaction product. This test was performed according to Denizot and Lang (1986). Briefly, $10 \mu \mathrm{l}$ of $1 \mathrm{mg} / \mathrm{ml}$ MTT (Merck, France) in PBS-glucose was added to each well containing $0.1 \mathrm{ml}$ of medium and the cells were returned to the incubator. After $2 \mathrm{hr}$ at $37^{\circ} \mathrm{C}$, the medium was removed and the dark-blue formazan formed was dissolved by the addition of $100 \mu \mathrm{l}$ of di-methyl sulfoxyde (DMSO) to each well. The absorbance of the reaction product was read at $570 \mathrm{~nm}$.

PKC activity measurements. Freshly dissociated rat cortical E16 neu- rons were treated $45 \mathrm{~min}$ in suspension in PBS without calcium $/ \mathrm{mag}$ nesium (GIBCO-BRL) at a density of $210^{6}$ cells $/ 200 \mu \mathrm{l}$. After incubation with the appropriate peptide(s), cells were washed by addition of $1.3 \mathrm{ml}$ of PBS, collected by centrifugation and quickly frozen on dry ice. For assaying PKC activity, cell pellets were resuspended in $2 \mathrm{ml}$ of ice cold homogeneizing buffer: $20 \mathrm{~mm}$ Tris-HCI pH 7.4, $10 \mathrm{~mm}$ 2-mercaptoethanol, $10 \mathrm{~mm}$ EGTA, $2 \mathrm{~mm}$ EDTA, $1 \mathrm{~mm}$ PMSF, $0.25 \mathrm{~m}$ sucrose, and $0.3 \%$ Triton $\mathrm{X}-100$, and homogenized at $0^{\circ} \mathrm{C}$. PKC was assayed by measuring the incorporation of ${ }^{32} \mathrm{P}$ from $\Lambda T P$ into MBP414 according to Sasaguri et al. (1993) with modifications. Briefly, the

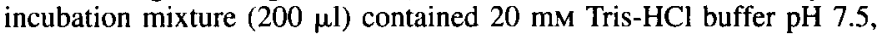
$0.5 \mathrm{~mm} \mathrm{MgCl}, 10 \mu \mathrm{M} \mathrm{MBP}_{4-14}, 50 \mu \mathrm{g} / \mathrm{ml}$ phosphatidyl serine, $5 \mu \mathrm{g} /$ $\mathrm{ml}$ dioleine, $10 \mu \mathrm{M}$ ATP, $\gamma-^{32} \mathrm{P}$ ATP $10^{6} \mathrm{dpm}$, and $50 \mu \mathrm{l}$ of the cell fraction. After incubation at $30^{\circ} \mathrm{C}$ for $10 \mathrm{~min}$, the reaction was stopped by the addition of $3 \mathrm{ml}$ of $20 \%$ trichloroactetic acid (TCA). Acid precipitable materials were collected on Whatman GF/C filters and extensively washed with ice-cold $20 \%$ TCA. The radioactivity on the filters was measured using a scintillation counter. PKC activity was corrected for nonspecific activity by assaying in the absence of $\mathrm{CaCl}_{2}$ with $1 \mathrm{~mm}$ EGTA. Results are expressed as pmoles of ${ }^{32} \mathrm{P}$ incorporated into $\mathrm{MBP}_{+14}$ f $\mathrm{min} / \mathrm{mg}$ protein.

${ }^{32} P$ Labeling of cellular proteins, two dimensional gel electrophoresis, two-dimensional peptide mapping. $\Lambda$ s previously described $(\Lambda \mathrm{r}-$ aujo et al., 1993), 3 week old primary cultures of mouse astrocytes were labeled for $4 \mathrm{hr}$ with $0.15 \mathrm{mCi}$ of ${ }^{32} \mathrm{PO}_{4}{ }^{3-}$ in $250 \mu$ l of phosphatefree medium. After two-dimensional-PAGE ( $\mathrm{pH}$ 6-4.5 isoelectric focusing gels followed by $13 \%$ polyacrylamide gels) ${ }^{32} \mathrm{P}$-labeled isoforms of PEA-15, $\mathrm{Pa}$, and $\mathrm{Pb}$ spots, were excised from two-dimensional gels and treated with thermolysin $(100 \mu \mathrm{g} / \mathrm{ml})$ at $37^{\circ} \mathrm{C}$ for 18 hr. The digests solubilized from the gel pieces were lyophilized, dissolved in $10 \mu \mathrm{l}$ of electrophoresis buffer ( $10 \%$ acetic acid, $1 \%$ pyridine, $\mathrm{pH} 3.5$ ) and applied on a cellulose-coated thin layer plate (20 $\times 20 \mathrm{~cm}$ ). Electrophoresis was carried out at $350 \mathrm{~V}$ for 1-2 hr, and the plate then subjected to chromatography with pyridine/butanol/acetic acid/water (37.5:25:7.5:30, by volume). After drying, plates were subjected to autoradiography.

Video time lapse recording. Dissociated neurons of rat embryonic cortex (E15) were plated on the surface of coverslip dishes coated with polyornithine as previously described (Lafont et al., 1993). After $24 \mathrm{hr}$, the culture dishes were transfered on the stage of an inverted microscope (Zeiss Axiovert 135) and kept inside an incubator chamber (Cultimat) which maintained the temperature at $37^{\circ} \mathrm{C}$. The incubator also maintained the $\mathrm{pH}$ of the medium by means of a stream of humiditied and warm $\mathrm{CO}_{2}(4 \%)$. An infrared filter and a shutter (Uniblitz) were inserted in the light path. Fibers were observed using a $40 \times$ phase contrast objective, and in some cases the image was further magnified using the 1.6× Optovar system of the microscope. Images were obtained with a Newvicon camera (Dage 70), and were further processed (Quantel). A computer controled the shutter opening and the image processor. Images were acquired at $60 \mathrm{sec}$ intervals, and were stored on the computer hard disk. Growth cones were recorded for 10-30 min before adding the coupled V-PKCi or the uncoupled $\mathrm{V}+\mathrm{PKCi}$ peptide mix. An aliquot diluted in $100 \mu$ l of culture medium was added to the culture (final concentration: $0.5 \mu \mathrm{M}$ ) and recording was continued for $30 \mathrm{~min}$.

\section{Results}

Internalization of a vector-coupled PKCi peptide (V-PKCi) into live cells

pAntp $\mathrm{p}_{43-58}$, a peptide identical to the third helix of the homeodomain of Antennapedia translocates through biological membranes (Derossi et al., 1994). We decided to use this sequence as a vector for the intracellular addressing of a Protein kinase $C$ inhibitor (PKCi) corresponding to PKC pseudosubstrate $\left[\mathrm{Ala}_{25}\right]$ $\mathrm{PKC}_{19-31}$ described by House and Kemp (1990). In order to be able to generate a disulfide bond between $\mathrm{pAntp}_{43-58}$ and $\mathrm{PKCi}$, a NPyS-cysteinyl residue was added to the N-terminal sequence of both peptides.

Coupling of the PKCi peptide to the pAntp $\mathrm{p}_{43-58}$ vector was performed by reduction of the thiol group on the $\mathrm{PKCi}$ peptide using TCEP in a molar $1 / 1$ ratio, followed by incubation with the NPyS-pAntp t3-58 $_{45}$ peptide (see Material and Methods for a 
Figure 1. Coupling PKC inhibitory peptide to the $\mathrm{pAntp}_{43-58}$ vector. $A$, Principle of the coupling reaction. $B$, Schematic structure of the V-PKCi coupled product. $C$, SDS-PAGE migration (without $\beta$-mercapto-ethanol) of and Coomassie blue staining of $\mathrm{PKCi}_{19.31}$ coupled to $\mathrm{pAntp}_{43-58}$ (lane 1 , upper band) or of the two uncoupled products (lower band in lanes 1 and 2). Note that the reaction yields approximately $50 \%$ of coupled product and that uncoupling with $10 \mathrm{~mm}$ DTT is quantitative (lane 2). A total of $10 \mu \mathrm{g}$ of peptide (V-PKCi or $\mathrm{V}+\mathrm{PKCi}$ ) were loaded in each lane. Note that the two peptides migrate with similar velocities.

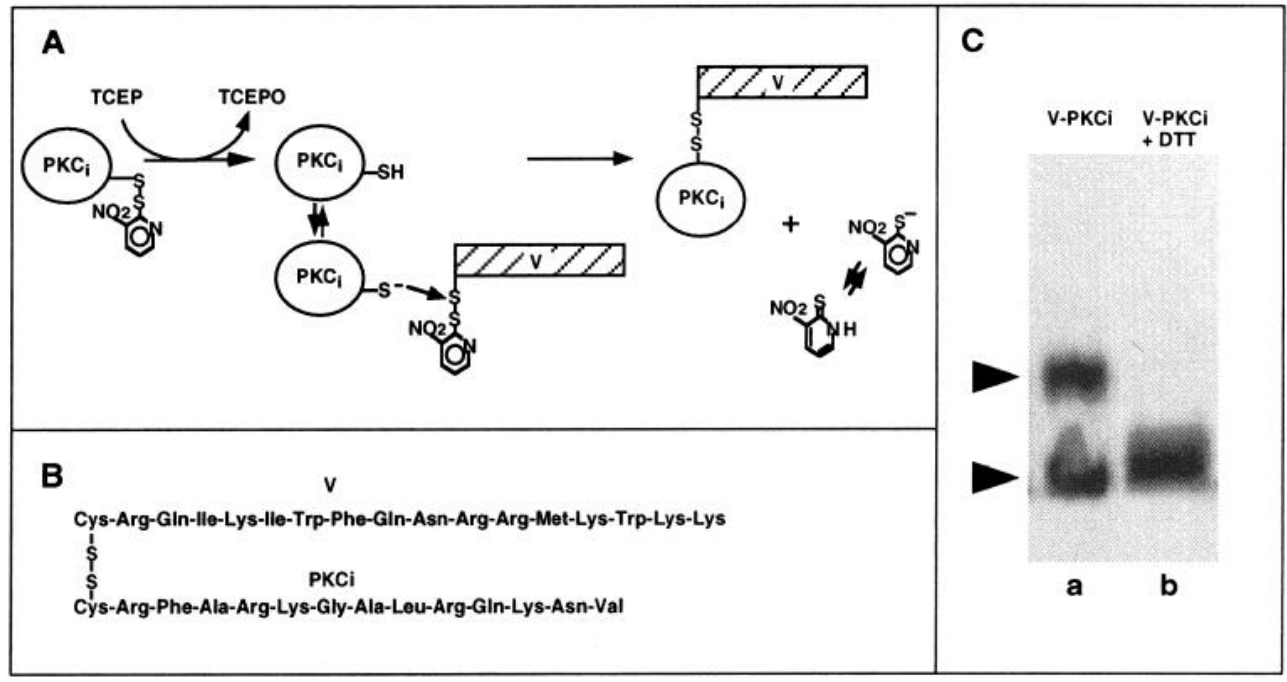

detailed protocol). This prevents the homodimerisation of $\mathrm{p}$ Antp $_{43.58}$ peptides, and leads preferentially to the formation of heterodimers. The reaction is schematized in Figure $1 A$ and the structure of the resulting coupled product, referred to in the entire text as vector-PKCi (V-PKCi), is described in Figure $1 B$. Coupling was monitored by SDS-PAGE, and the coupled peptide was purified by HPLC. In all cases, coupling of the PKCi peptide to the pAntp p3-58 vector yields above $50 \%$ of coupled product (V-PKCi, Fig. 1C, lane a). Treating V-PKCi with DTT quantitatively uncouples the heterodimer (Fig. $1 C$, lane b).

To follow its translocation through cytoplasmic membranes, the PKCi peptide was biotinylated and then coupled to the unlabeled vector. Primary neuronal cell cultures were incubated with biotinylated $\mathrm{V}-\mathrm{PKCi}$ at $1.5 \mu \mathrm{M}$ for $1 \mathrm{hr}$ at $37^{\circ} \mathrm{C}$, washed and fixed. The biotinylated peptide was then detected using streptavidin-FITC. Figure 2 shows that biotinylated $\mathrm{PKCi}$ is present in all cells (Fig. 2A). The use of confocal microscopy establishes that the peptide is actually within the cells and in all compartments, including cell body and neurites (Fig. 2A). Internalization of $\mathrm{PKCi}$ is dependent on its linkage to the vector since it is abolished by a brief treatment with disulfide bond reducing agents (Fig. 2B).
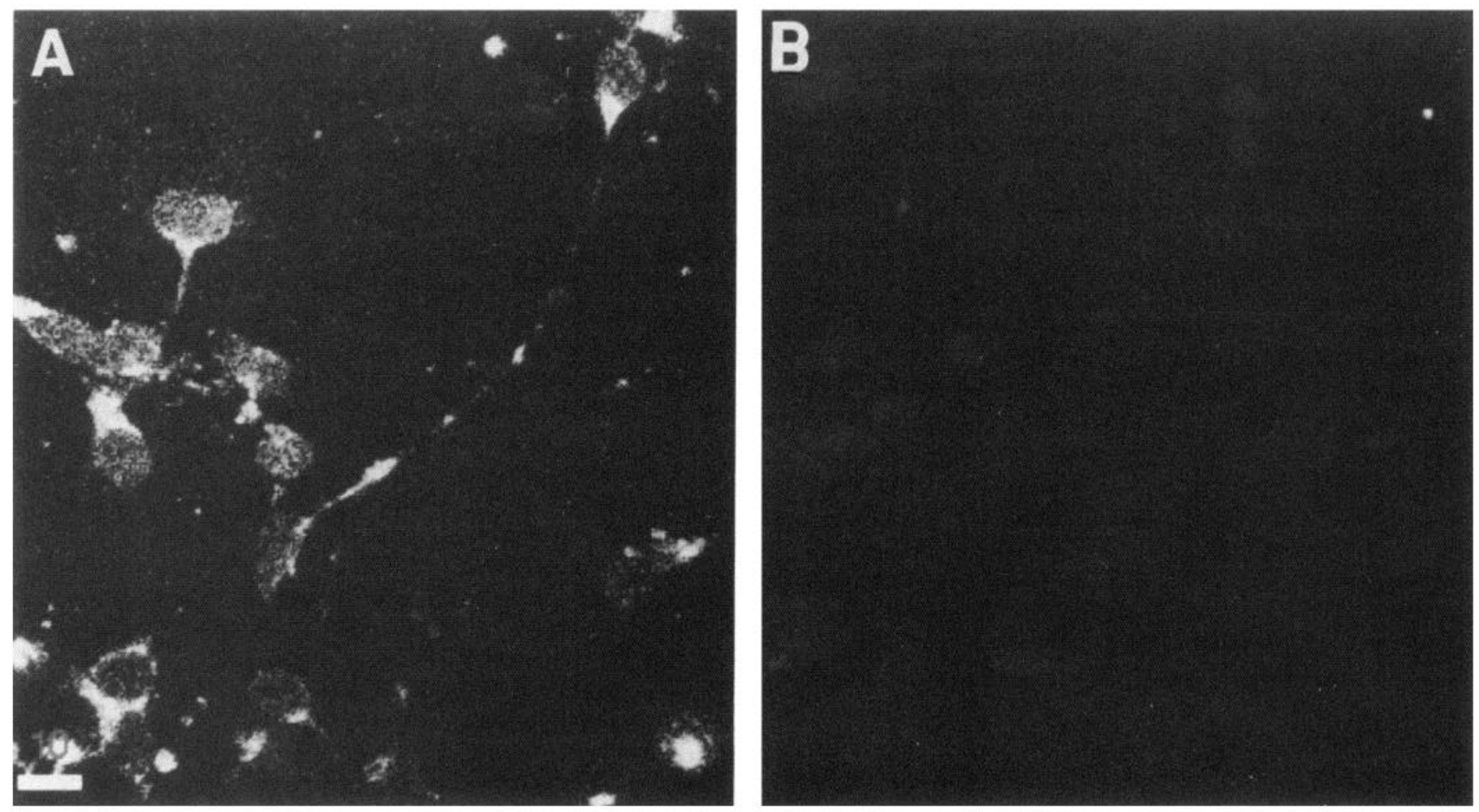

Figure 2. Internalization of a biotinylated PKC inhibitory peptide in primary neuronal cells. Primary neuronal cell cultures were incubated for 1 $\mathrm{hr}$ at $37^{\circ} \mathrm{C}$ with the V-PKCi biotinylated on the PKCi domain $(A)$ or with a mixture of $\mathrm{V}$ and PKCi-biotin in wich the N-terminal thiol was linked to a cysteine residue $(B)$. The biotinylated peptide was detected using streptavidin-FITC. $A$ and $B$ show two confocal sections scanned at the same intensity. Scale bar, $5 \mu \mathrm{m}$. 
A

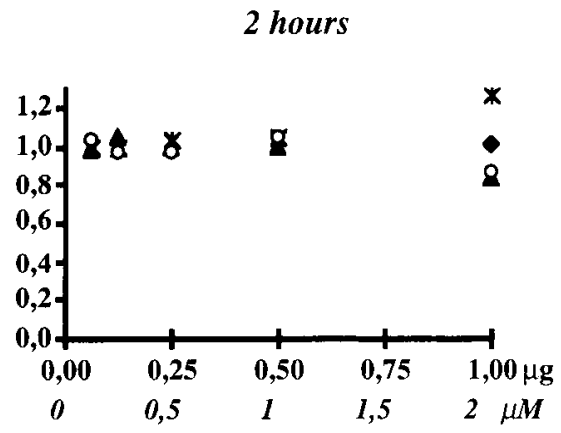

B

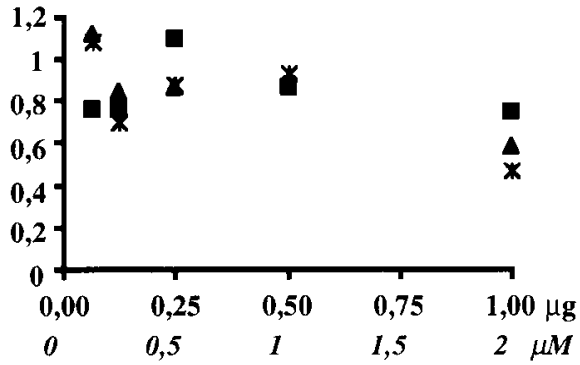

Figure 3. Absence of toxicity of V-PKCi. Primary neuronal cells were cultured in 96 well culture plate at a density of $10^{5}$ cells/well in $100 \mu \mathrm{l}$ of serum-free medium. Twenty-four hours after plating, the cells were incubated for $2 \mathrm{hr}$ with increasing peptide concentrations and washed. Respiratory activity was measured immediately $(A)$ or $48 \mathrm{hr}$ later $(B)$. The concentration of V-PKCi ([V-PKCi]) added to the culture is indicated in $\mu \mathrm{g} / \mathrm{ml}$ and in $\mu \mathrm{M}$. The ratio of the $\mathrm{OD}_{57 / \text { mun }}$ readings between V-PKCi treated and untreated cells is indicated in ordinate.

Before assaying the biological activity of $\mathrm{V}-\mathrm{PKCi}$ in live cells, toxicity test were performed in primary neuron cultures after treatment with V-PKCi. Toxicity was monitored by comparing the mitochondrial activity (MTT test; see Material and Methods) in cells treated or not with $\mathrm{V}-\mathrm{PKCi}$ at concentrations up to 2 $\mu \mathrm{M}\left(1 \mu \mathrm{g} / 100 \mu \mathrm{l}\right.$; $10^{5}$ cells per well). Results in Figure $3 \mathrm{~A}$ demonstrate that a 2 hr incubation has no effect on cell survival at any of the tested concentrations. Survival of $\mathrm{V}$-PKCi treated cells was also measured in a protocol including a $2 \mathrm{hr}$ incubation followed by $48 \mathrm{hr}$ of recovery in $\mathrm{V}$-PKCi free medium. In the latter conditions, a slight toxicity could be seen at the highest concentration $(2 \mu \mathrm{M})$ but not at concentrations of up to $1 \mu \mathrm{M}$ (Fig. 3B). Therefore, all experiments described below were performed at a nontoxic concentration of $0.5 \mu \mathrm{M}\left(300 \mu \mathrm{l}\right.$ and $10^{5}$ cells per well) of coupled V-PKCi peptide.

\section{$V$-PKCi peptide is a specific inhibitor of $P K C$ in live neurons and astrocytes}

The $\mathrm{PKCi}$ peptide, in the micromolar range, has been shown to inhibit specifically the phosphorylation of PKC sites in vitro or in permeabilized cells. We tested whether, at an extracellular concentration of $0.5 \mu \mathrm{M}$, the coupled peptide would be functional in live cells. Rat brain embryonic cells were dissociatcd, incubated with V-PKCi or with the uncoupled compound for 45 min and treated or not with $1 \mu \mathrm{M}$ PMA for $5 \mathrm{~min}$. Cells were washed, fractionated between membrane and cytosol and each fraction was incubated with the $\mathrm{MBP}_{4-14}$ peptide substrate for

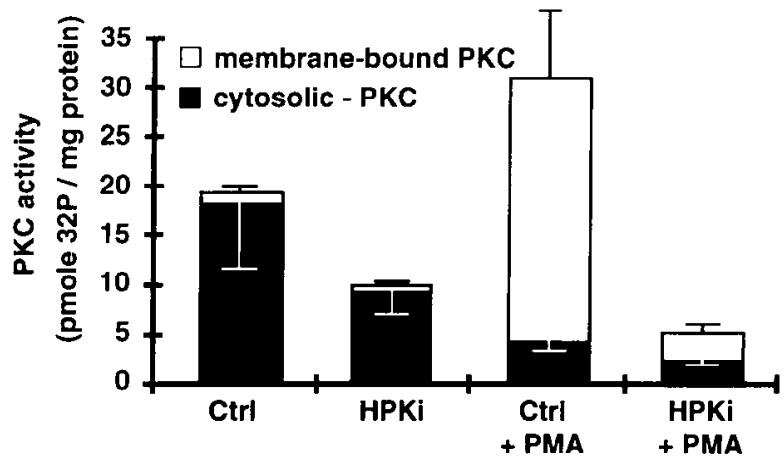

Figure 4. Internalized V-PKCi inhibits $\mathrm{PKC}$ activity ex vivo. V-PKCi $(H P K i)$ and the uncoupled $\mathrm{V}+\mathrm{PKCi}(\mathrm{Ctrl})$ mixture were added at the same concentration $(0.5 \mu \mathrm{M})$. PMA treatment was carried out for $5 \mathrm{~min}$ at $1 \mu \mathrm{M}$. Measurements were performed in triplicates; vertical bars indicate the SD.

PKC in the presence of $\gamma^{-3}$ P ATP. PKC activity was determined by measuring the incorporation of ${ }^{32} \mathrm{P}$ in TCA precipitable proteins.

In the absence of PMA, PKC activity is essentially cytosolic. When compared to that observed with the uncoupled peptide, basal PKC activity is inhibited by about $50 \%$ following a 45 min incubation with V-PKCi (Fig. 4). Addition of PMA (1 $\mu \mathrm{M})$ activates $\mathrm{PKC}$ and provokes its translocation from the cytoplasin to the membrane. In the latter condition, preincubation with V-PKCi leads to a 10-fold decrease in total PKC activity, mainly affecting the membrane-associated activity.

The synthetic autoinhibitory domain $\mathrm{PKC}_{19-31}$ peptide (PKCi), in addition to its known ability to inhibit PKC activity strongly in vitro $\left(\mathrm{IC}_{50}<1 \mu \mathrm{M}\right)$, also inhibits the Calcium/Calmodulindependent protein kinase II (CaMK-II), although at a much higher concentration $\left(\mathrm{IC}_{50}=30 \mu \mathrm{M}\right.$ ) (Smith et al., 1990). To test the kinase-selectivity of V-PKC $i$ in intact cells, we assayed its effect on the phosphorylation of PEA-15, an endogenous substrate for both CaMK-II and PKC (Araujo et al., 1993; Danziger et al., 1995). PEA-15 is highly enriched in astrocytes and exists under an unphosphorylated form and two phosphorylated forms: $\mathrm{Pa}$ (phosphorylation on $\mathrm{Ser}_{116}$ by $\mathrm{CaMK}-\mathrm{II}$ ) and $\mathrm{Pb}$ which derives from $\mathrm{Pa}$ by an additional PKC-dependent phosphorylation on Ser $_{104}$ (Chneiweiss et al., unpublished observations). Astrocytes were labeled with ${ }^{32} \mathrm{P}$ phosphate, treated for $30 \mathrm{~min}$ with coupled or uncoupled (control) V-PKCi with or without 100 nM PMA, and phosphopeptide mapping of $\mathrm{Pb}$ was performed (Fig. 5). When compared to the control, V-PKCi strongly decreased the level of phosphorylation of the PKC sites (arrowheads) even in the presence of PMA. In contrast, the level of phosphorylation of the CamK-II site (arrow) was not affected by V-PKCi treatment, thus demonstrating that $\mathrm{V}-\mathrm{PKCi}$ at $0.5 \mu \mathrm{M}$ could be used as a specific ex vivo PKC inhibitor.

$V$-PKCi provokes a strong modification in growth cone morphology

Dissociated embryonic (E15) rat cortical neurons were plated on polyornithine-coated glass coverslips and grown in serumfree medium. After $48 \mathrm{hr}$, when well-developed neurites and distinct growth cones are visible, the cells were incubated with the inhibitory peptide at a concentration of $0.5 \mu \mathrm{M}$. The effect of V-PKCi was first assayed using video time lapse recording. Fields were selected for the presence of a growth cone actively growing for at least $10 \mathrm{~min}$ before treatment. The addition of 


\section{V-PKCi}
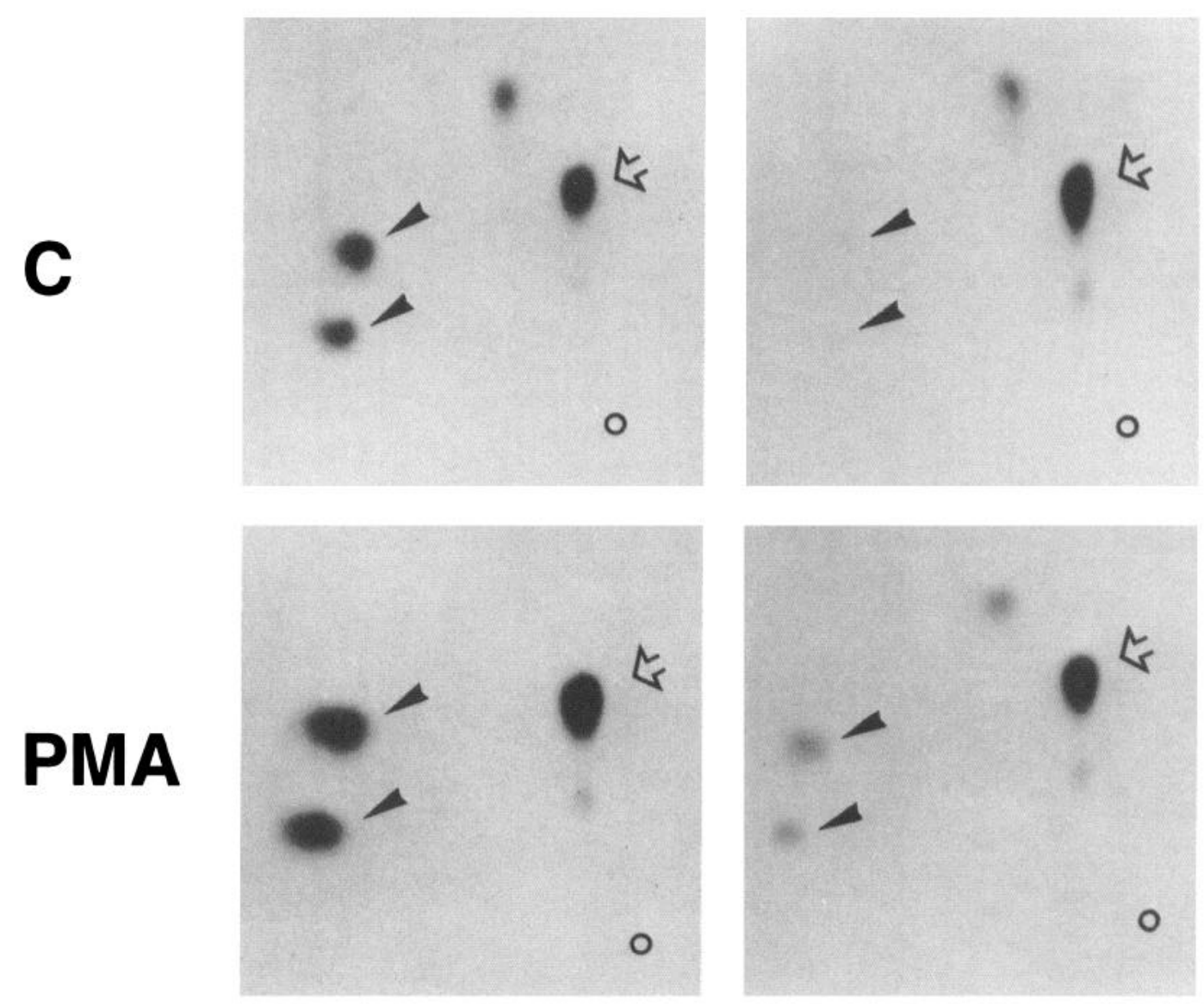

Figure 5. Two-dimensional peptide mapping of PEA15. The Pb form of PEA-15 was cut out from 2D-PAGE gels performed with homogenates from ${ }^{32} \mathrm{P}$-labeled astrocytes. Labeled phosphoprotein $(500-1500 \mathrm{cpm}$, Cerenkov counting) was subjected to thermolysin digestion and analyzed on chromatographic plates. The open circles indicate the origin where the thermolysin digest was applied. Open arrowheads indicate the peptide containing the CaMK-II site, whereas bold arrowheads point to the two peptides containing the seryl residue phosphorylated by PKC.

the uncoupled mixture of $\mathrm{PKCi}$ and vector (control), did not affect growth cone activity (Fig. 6A). In contrast, V-PKCi induced a dramatic morphological modification characterized by a rapid (within $3 \mathrm{~min}$ ) retraction of the filopodes (Fig. 6B,C). This phenomenon was in many cases followed by a retraction of the intra-shaft material, leaving a phantom of membranous material on the substrate, often seen in collapsing neurites (Fig. $6 C)$.

A statistical morphometric analysis allowed us to analyze the effect of V-PKCi at the level of the entire population of growth cones present in the culture. Cells were plated at low density $\left(10^{4}\right.$ cells $/ 24$ plate well), grown for $48 \mathrm{hr}$, treated with coupled or uncoupled V-PKCi $(0.5 \mu \mathrm{M})$ or with V-PKCc. PKCc differs from $\mathrm{PKCi}$ by 1 amino acid and presents no inhibitory activity (House and kemp, 1990). After different periods of time, cells were fixed and immunolabeled for N-CAM to facilitate the detection of growth cones and the analysis of their shape. In each condition, 50 neurons were randomly chosen and the surface of the growth cone was measured using the IMSTAR software. Since uncoupling of V-PKCi is achieved by adding DTT (1 $\mathrm{mM})$ to the concentrated peptide solution, thereby leading to the presence of $6 \mathrm{nM}$ DTT in the cultures, we verified that this concen- tration of DTT had no effect on the growth cone surface (Fig. $7 A$ ). Figure $7 B$ illustrates the percentage distributions according to growth cone surfaces between cells treated for different periods of time $(10,30$, and $120 \mathrm{~min})$ with coupled or uncoupled V-PKCi at the same molarity. As demonstrated in Figure 7, C and $D$, the internalization of PKCc, a peptide devoid of inhibitory activity has no effect on growth cone morphology. Identical results were observed when neurons were grown on a different substratum, in particular polyornithine-laminin instead of polyornithine (data not shown).

\section{Discussion}

In this study we have used a newly discovered system of vectorization to introduce the PKC pseudosubstrate sequence into the cytoplasmic compartment of live cells. We demonstrate that linkage of PKCi to the vector allows its internalization, resulting in specific inhibition of PKC and growth cone collapse.

\section{Definition of the vector peptide}

The vector peptide was designed following the finding that the 60 amino-acid-long homeodomain of the transcription factor Antennapedia could translocate through biological membranes (Jo- 


\section{Control}
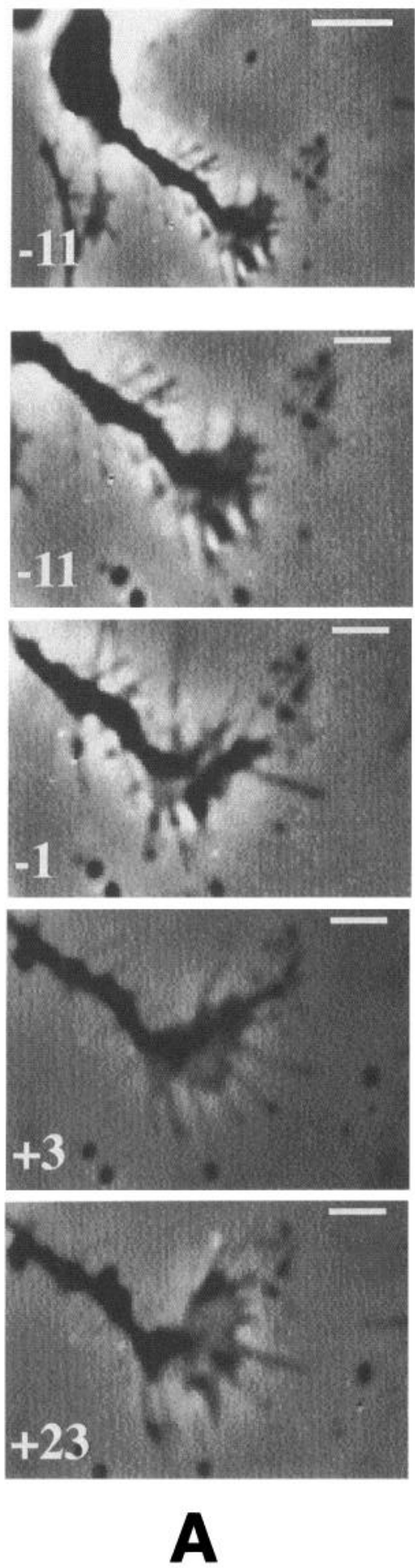
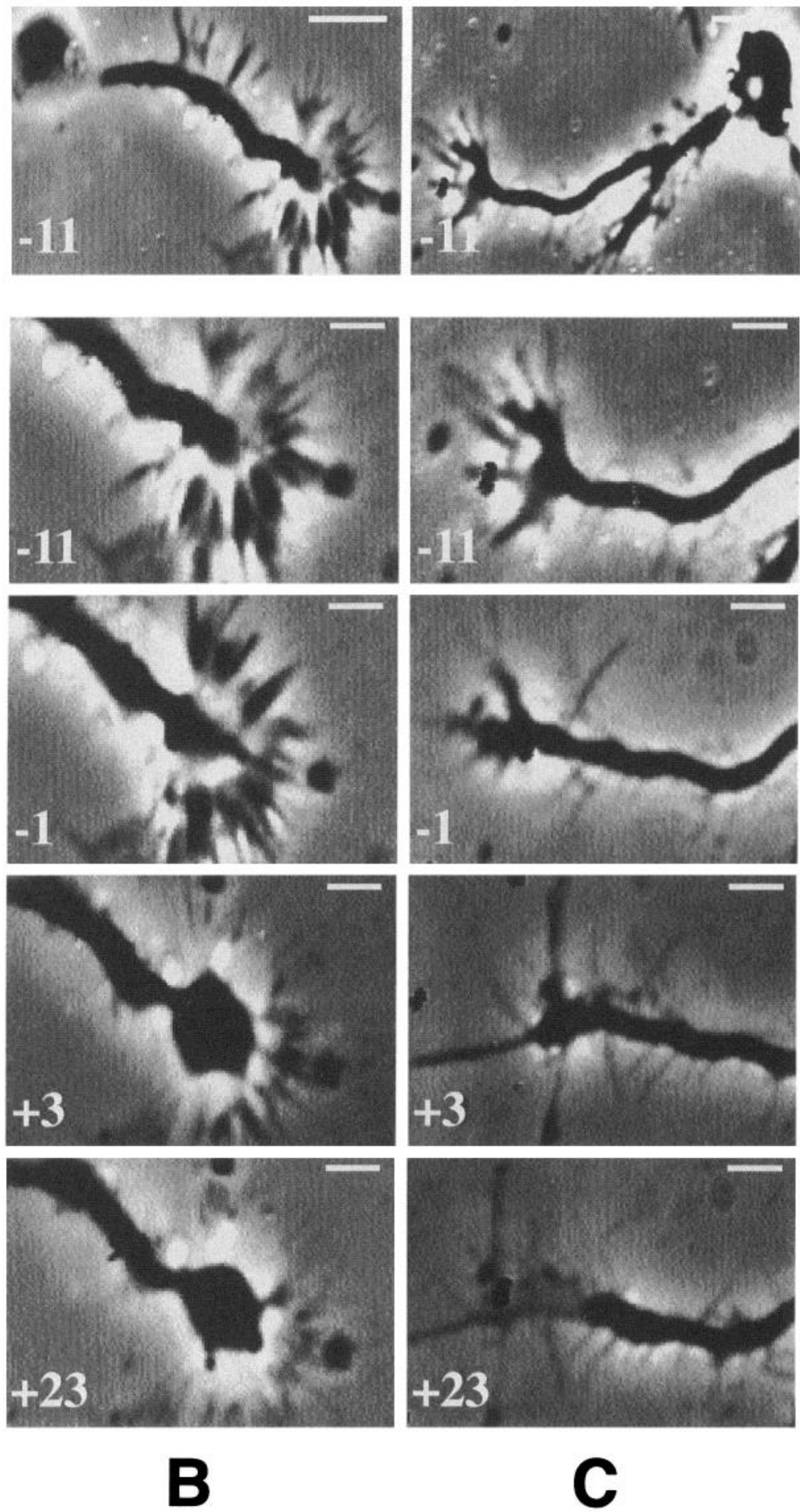

Figure 6. V-PKCi provokes a rapid change in growth cone morphology. Video time lapse recording showing the kinetics of growth cone morphological modification induced by the PKCi inhibitory peptide. In the left panel is a control growth cone treated with uncoupled $\mathrm{V}$ and PKCi. In the two right panels are two growth cones representative of the typical morphological effects observed after treatment with V-PKCi. Scale bar: 10 $\mu \mathrm{m}$. 
A

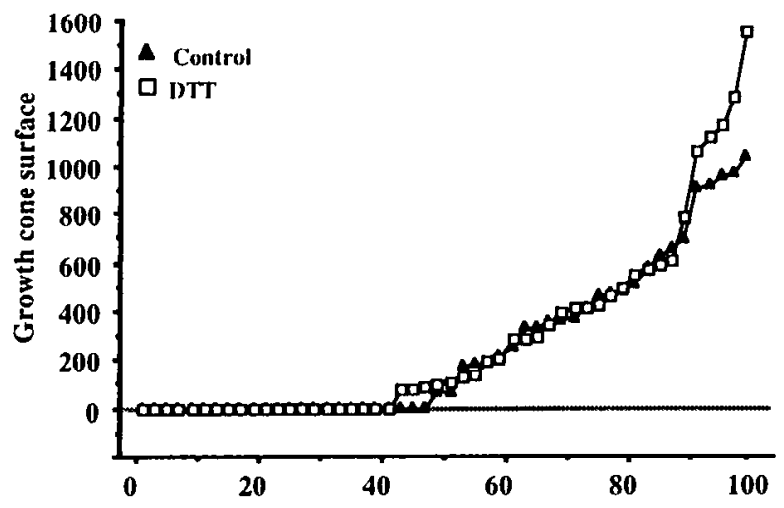

C

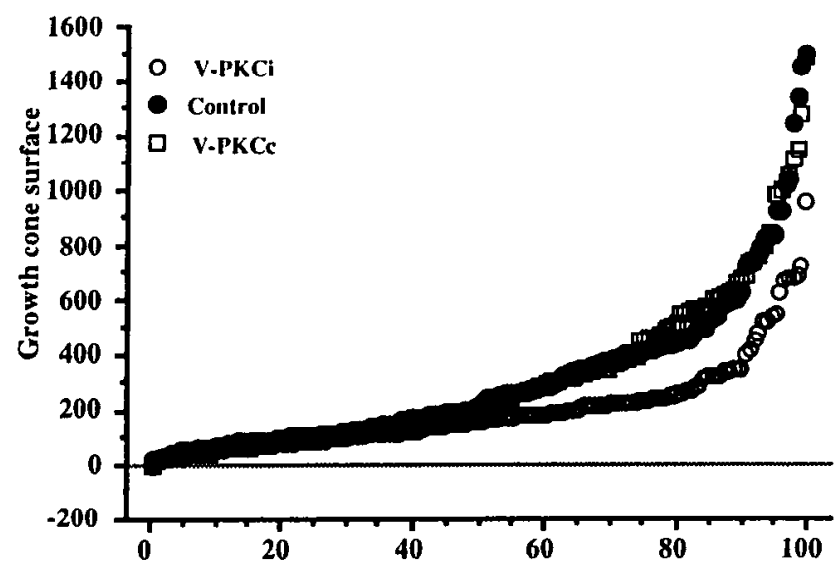

B

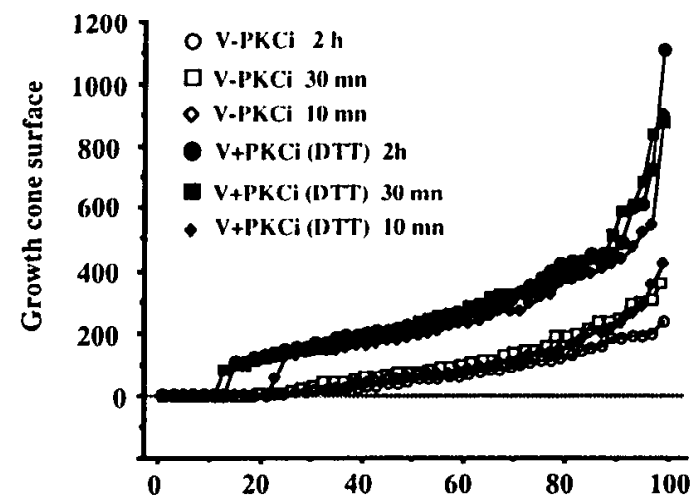

D

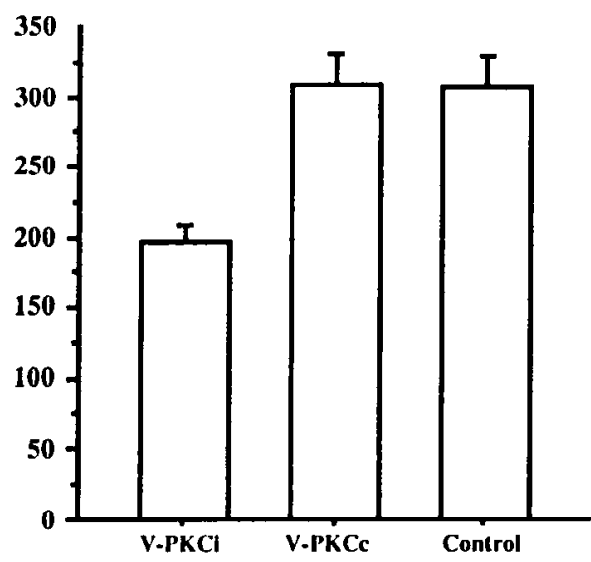

Figure 7. Percentage distributions of growth cone according to their surface. A, Comparison of distributions in control cells and DTT-treated cells. $B$, Comparison of distributions in cells incubated for various periods of time either with $\mathrm{V}-\mathrm{PKCi}$ or with uncoupled $\mathrm{V}+\mathrm{PKCi}$. For each condition, the surface of 50 growth cones was measured after NCAM immunostaining. These distributions were statistically analyzed (sTATwORK from Cricket Software Philadelphia). Any distribution with coupled peptides (open symbols) differs significantly from any distribution with uncoupled peptide (solid symbols) $(P<0.001)$. No difference was observed between 10 and $120 \mathrm{~min}$ of incubation. $C$, Comparison between control and cells incubated for $30 \mathrm{~min}$ either with the inhibitor (V-PKCi) or a modified version of the inhibitor without biological activity (V-PKCc). $D$, Histograms showing the means and SEM corresponding to the experiment in $C$. V-PKCi differs significantly from V-PKCc $(p<0.001$, Student's $t$ test)

liot et al., 1991a; Bloch-Gallego et al., 1993). Translocation which also occurs at $4^{\circ} \mathrm{C}$, and thus does not depend on classical endocytosis, was exploited to internalize oligonucleotides (Allinquant et al., 1995) or fusion proteins composed of the entire homeodomain and of various peptidic sequences (Perez et al., 1992, 1994).

Site-directed mutagenesis of pAntp (Le Roux et al., 1993) allowed to define a smaller peptide, pAntp s3-5x $_{\text {. }}$ that retains pAntp internalization properties. This peptide corresponding to the 16 amino-acid-long third helix of the homeodomain, indeed translocates through biological membranes at both $4^{\circ} \mathrm{C}$ and $37^{\circ} \mathrm{C}$ (Derossi et al., 1994). We thus decided to investigate whether the third helix of the homeodomain could be used to introduce bioactive compounds inside live cells, in particular oligonucleotides (Troy et al., 1994) and oligopeptides (this study).

\section{Internalization of $\mathrm{PKCi}$}

The lack of specific PKC inhibitors capable of crossing biological membranes and/or devoid of secondary effects renders previous results on the role of $\mathrm{PKC}$ in neurite elongation rather circumstantial. Therefore, we have decided to internalize the PKC peptidic pseudosubstrate, a small peptide (13 amino acids), presenting a highly specific biological activity.

Internalization of the PKCi requires its covalent linkage to the vector peptide through a disulfide bridge. This bridge is not stable within the cells, because of the reductive properties of the cell cytoplasm (presence of glutathion). The half-life of disulfide bonds between the homeodomain peptide and another compound is approximately $60 \mathrm{~min}$ (unpublished results).

The mode of internalization of the vector is not known. The homeodomain and its third helix translocate through the plasma membrane of different cell types, including neurons, fibroblasts, anterior pituitary cells, muscle cells, astrocytes, macrophages, lymphocytes, and oligodendrocytes (Joliot et al., $1991 \mathrm{a}$; Perez et al., 1992, 1994; and unpublished results). Internalization is enhanced by the presence of polysialic acid (PSA) present on immature neuronal cell adhesion molecule (Joliot et al., 1991b). In spite of the enhancing effect of PSA, translocation per se is not receptor dependent, since it occurs at $4^{\circ} \mathrm{C}$ (Joliot et al., 1991 b; Derossi et al., 1994) and since a peptide vector composed 
of D-amino acids is also internalized (D. Derossi, S. Calvet, A. Prochiantz, A. Brunissen, and G. Chassaing, unpublished observations).

Whatever the exact mechanism of translocation, it is important to stress that, bccausc intcrnalization of pAntp ${ }_{43-58}$ does not depend on classical endocytosis, the linked peptide does not travel through endosomal and lysosomal compartments. Consequently, its resistance to proteolytic degradation and general activity in most cellular compartments are enhanced.

\section{Protein kinase $C$ inhibition}

In the absence of stimulation by the phorbol ester PMA, PKC. is primarily cytosolic and its inhibition by the internalized PKCi is only $50 \%$. Interestingly, the association of PKC with membranes, provoked by the addition of PMA (which also stimulates the activity) allows an almost complete inhibition by the internalized inhibitor. Although we have no direct explanation for this phenomenon, we propose that enhanced inhibition upon PMA treatment is primarily due to the demasking of the catalytic site (normally occupied by the $\mathrm{N}$-terminus of the enzyme), making it accessible for the exogenous inhibitory peptide.

The total inhibition of PKC activity demonstrates that the internalized peptide inhibits all PKC isoforms present in embryonic cortical neurons. Because of this strong effect, it was important to determine whether the amount of peptide internalized was not interfering with other kinases, in particular CaMK-II, which can be inhibited in vitro by the $\mathrm{PKCi}$ pseudosubstrate at concentrations above $30 \mu \mathrm{M}$ (Smith et al., 1990). By following the pattern of phosphorylation of PEA-15, a protein enriched in astrocytes with both PKC and CaMK-II target sites, we showed that in the micromolar (extracellular) range used in our study, the effect of the internalized PKCi is specific for PKC phosphorylation sites.

\section{Growth cone morphology}

The addition of V-PKCi on neurons provoked a rapid retraction of the filopodes and lamellipodes. At the same time, the core of the growth cone became globular and increased in size. This process occured within 3 min suggesting an action of $\mathrm{PKCi}$ directly at the level of the cone. Such an immediate effect requires that the peptide be internalized very efficiently, reaching rapidly a concentration sufficient to inhibit PKC in the growth cones. This is in agreement with our previous results showing that $20 \%$ of homeodomain peptides present in the culture medium are internalized within 2 hr (Le Roux et al., 1993).

In many occasions we observed a retraction of a dense material present in the distal region of the neurite shaft, with some membranous structures remaining intact. Filopode retraction and withdrawal of the intracellular material at the level of the growth cone suggest that the action of PKC occurs through the modification of the cytoskeleton, very likely at the level of actin and tubulin polymerization. Interestingly, a maximal effect was observed after 10 min with no further change in the apparent morphology of the growth cone occuring between $10 \mathrm{~min}$ and $2 \mathrm{hr}$. The latter effects differed from those observed with staurosporine or $\mathrm{H7}$, two other PKC inhibitors which, in addition to provoking growth cone collapse, had profound and slowly developing effects on the general morphology of the cells (not shown).

\section{Interpretations and further experiments}

In the literature, the evidence that PKCs play a role in growth cone shape and motility is primarily based on the use of lipo- philic inhibitors or on the desensitization of the enzymes by the addition of high concentrations of phorbol-ester. The latter protocols, although suggestive of a role for PKC in the motility of neuronal growth cones, suffer from the pleiotropic effects of the drugs on neuronal physiology. We thus believe that the use of the vector peptide to internalize the PKC pseudosubstrate in neurons in culture is a technical breakthrough, strongly suggesting that $\mathrm{PKC}$ is a key regulator of growth cone morphology. This strategy could be used to internalize several other substances into the nerve terminal, thus providing a very useful approach in the field of neuropharmacology.

The observation that inhibiting PKCs provokes a collapse of all growth cones is interesting because these enzymes may provide a site of integration for several transducing events leading to distinct modifications of the cytoskeleton, for example, actin severing (Fan et al., 1993; Neely and Gresemann, 1994). The presence of PKC isoforms in the growth cones has been reported (Campenot et al., 1994), including that of PKCE, a calciumindependent isoform and possible target of thrombin-induced remodeling (Suidan et al., 1992).

Recent reports indeed underscore the role of dynamic remodeling of cytoskeletal components, neurofilaments, microtubules, and actin, on neuronal pathfinding decisions (Fan et al., 1993; Lafont et al., 1993; Lin and Forscher, 1993; Lafont and Prochiantz, 1994; Tanaka et al., 1995). In this context, it is interesting to note that some PKC targets should modify the state of polymerization of the cytoskeleton or its anchoring to the cellular membranes. Among these targets are proteins that regulate tubulin polymerization such as Dynamin, a GTPase localized in nerve terminals (Robinson et al., 1993) or MAP2 and Tau, two microtubule associated proteins involved in the elongation of dendrites and axons, respectively (Caceres et al., 1991; Correas et al., 1992; Ainsztein and Purich, 1994; Lafont and Prochiantz, 1994).

Other targets of interest are two major PKC substrates, MARCKS (myristoylated alanine-rich C-kinase substrate), and the growth associated protein GAP43 (Aderem, 1992; Meiri et al., 1986). A role for GAP-43 in axonal elongation has been demonstrated (Shea et al., 1991; Baetge et al., 1992). In addition, it has been shown that phosphorylation of $\mathrm{Ser}_{41}$ in GAP-43 by PKC is necessary for activity (Widmer and Caroni, 1993). Both MARCKS and GAP43 (Meiri and Gordon-Weeks, 1990) can associate with cytoskeletal components in particular with actin filaments (Lin and Forscher, 1993), and with a complex containing tubulin and actin together with fodrin, talin and $\alpha$-actinin, respectively (Meiri and Gordon-Weeks, 1990).

The aim of this study was limited to testing, using a newly developed technology, whether PKC enzymes are involved in growth cone physiology. It is now necessary to identify PKC targets present in the cones and to analyze how the degree of phosphorylation of these targets correlates with their biological activity at the molecular level and at a more integrated level. For this latter objective, one needs to design compounds capable of interfering specifically with distinct sites of the many components of the growth cone machinery and to introduce them into the cell. Approaches similar to that presented here should prove useful in this perspective.

\section{References}

Aderem A (1992) The MARCKS brothers: a family of protein kinase C substrates. Cell 71:713-716.

Ainsztein AM, Purich DL (1994) Stimulation of tubulin polymerization 
by MAP-2. Control by protein kinase C-mediated phosphorylation at specific sites in the microtubule-binding region. J Biol Chem 269: 28465-28471

Allinquant B, Hantraye P, Mailleux P, Moya K, Bouillot C, Prochiantz A (1995) Downregulation of amyloid precursor protein inhibits neurite outgrowth in vitro. J Cell Biol 128:919-928.

Araujo H, Danzinger N, Cordier J, Glowinski J, Chneiweiss H (1993) Characterization of PEA-15, a major substrate for protein kinase $\mathrm{C}$ in astrocytes. I Biol Chem 268:5911-5920.

Azzi A, Boscoboinic D, Hensey C (1992) The protein kinase C family. Eur J Biochem 208:547-557.

Baetge EE, Hammang JP, Gribkoff VK, Mciri KF (1992) The role of GAP-43 in the molecular regulation of axon outgrowth and electrical excitability. Persp Dev Neurobiol 1:21-28.

Barja P, Alavi-Nassab A, lurck CW, Freire-Moar J (1994) Inhibition of $\mathrm{T}$ cell activation by protein kinase $\mathrm{C}$ pseudosubstrates. Cell Immunol 153:28-38.

Bentley D, O'Connor TP (1994) Cytoskeletal events in growth cone steering. Curr Opinion Neurobiol 4:43-48.

Bloch-Gallego E, LeRoux I, Joliot AH, Volovitch M, Henderson CE, Prochiantz A (1993) Antennapedia homeobox peptide enhances growth and branching of embryonic chicken motoneurons in vitro. J Cell Biol 120:485-492.

Caceres A, Potrebic S, Kosik KS (1991) The effect of tau antisense oligonucleotides on neurite formation of cultured cerebellar macroneurons. J Neurosci 11:1515-1523.

Campenot RB, Draker DD, Senger DL (1994) Evidence that protein kinase $\mathrm{C}$ activities involved in regulating neurite growth are localized to distal neurites. J Neurochem 63:868-878.

Correas I, Diaz-Nido J, Avila J (1992) Microtubule associated protein Tau is phosphorylated by protein kinase $\mathrm{C}$ on its tubulin binding domain. J Biol Chem 267: 15721-15728.

Danziger N, Yokoyama M, Jay T. Cordier J, Glowinski J, Chneiweiss H (1995) Cellular expression, developinenal regulation, and phylogenic conservation of PEA-15, the astrocytic major phosphoprotein and protein kinase C substrate. J Neurochem 64:1016-1025.

Decker LV, Parker PJ (1994) Protein kinase C: A question of specificity. Trends Biol Sci 19:73-77.

Denizot F, Lang R (1986) Rapid colorimetric assay for cell growth and survival; modifications to the tetrazolium dye procedure giving improved sensitivity and reliability. $J$ Immunol Methods 89:271-277.

Derossi D, Joliot AH, Chassaing G, Prochiantz A (1994) The third helix of the antennapedia homeodomain translocates through biological membranes. J Biol Chem 269:10444-10450.

Doherty P, Furness J, Williams E, Walsh FS (1994) Neurite outgrowth stimulated by the tyrosine kinase inhibitor herbimycin A requires activation of tyrosine kinases and protein kinase $C$. J Neurochem 62 : 2124-2131.

Eichholtz T, Bont DB, Widt JD, Liskamp RM, Ploegh HL (1993) A myristoylated pseudosubstrate peptide, a novel protein kinase $C$ inhibitor. J Biol Chem 268:1982-1986.

Fan J, Mansfield SG, Redmont T, Gordon-Weeks PR, Raper JA (1993) The organization of $F$-actin and microtubules in growth cones exposed to a brain derived collapsing factor. J Cell Biol 121:867-878.

House C, Kemp BE (1990) Protein kinase C pseudosubstrate prototope: structure-function relationship. Cell signalling 2:187-190.

Hvalby O, Hemmings HCJ, Paulsen O, Czernik AJ, Nairn AC, God fraind JM, Jensen V, Raastad M, Storm JF, Andersen P, Greengard P (1994) Specificity of protein kinase inhibitor peptides and induction of long term potentiation. Proc Natl Acad Sci USA 91:4761-4765.

Jalava A, Ackerman K, Heikkilia I (1993) Protein kinase inhihitor, statırosporine, induces a mature neuronal phenotype in SH-SY5Y human neuroblastoma cells through an $\alpha_{-}, \beta_{-}, \zeta$-protein kinase $\mathrm{C}$-independent pathway. J Cell Physiol 155:301-312.

Joliot AH, Pernelle C, Deagostini-Bazin H, Prochiantz A (1991a) Antennapedia homeobox peptide regulates neural morphogenesis. Proc Natl Acad Sci USA 88:1864-1868.

Joliot AH, Triller A, Volovitch M, Pernelle C, Prochiantz A (199/b) Alpha-2,8 polysialic acid is the neuronal surface receptor of Antennapedia homeobox peptide. New Biol 3:1121-1134.

Kapfhamer J, Raper JA (1987) Collapse of growth cone structure on contact with specific neurites in culture. J Neurosci 7:201-212.

Kaprielian Z, Patterson PH (1994) The molecular basis of retinotectal topography. Bioessays 16:1-11.
Kemp B (1991) Pscudosubstrate-based peptide inhibitors. Methods Enzymol 201:287-304.

Lafont F, Prochiantz A (1994) Region-specific neuro-astroglial interactions in neuronal morphogenesis and polarity. From homeogenic induction to cellular cytomechanics. Persp Dev Neurobiol 2:259260.

Lafont F, Rouget M, Triller A, Prochiantz A, Rousselet A (1992) In vitro control of neuronal polarity by glycosaminoglycans. Development 114:17-29.

Lafont F, Rouget M, Rousselet A, Valenza C, Prochiantz A (1993) Specific responses of axons and dendrites to cytoskeleton perturbations: an in vitro study. J Cell Sci 104:433-443.

Le Roux I, Joliot AH, Bloch-Gallego E, Prochiantz A, Volovitch M (1993) Neurotrophic activity of the antennapedia homeodomain depends on its specific DNA-binding properties. Proc Natl Acad Sci USA 90:9120-9124.

Letourneau P, Condic ML, Snow DM (1994) Interactions of developing neurons with the extracellular matrix. J Neurosci 14:915-928.

Lin C-H, Forscher P (1993) Cytoskeletal remodeling during growth cone-target interactions. J Cell Biol 121:1369-1383

Meiri KF, Gordon-Weeks PR (1990) GAP-43 in growth cones is associated with areas of membrane that are tightly bound to substrate and is a component of a membrane skeleton subcellular fraction. $J$ Neurosci 10:256-265.

Meiri KF, Pfenninger KH, Willard MB (1986) Growth associalted protein, GAP-43, a polypeptide that is induced when ncurons extend axons, is a component of growth cones and corresponds to pp46, a major polypeptide of a subcellular fraction enriched in growth cones. Proc Natl Acad Sci USA 83:3537-3541

Neely MD, Geeseman M (1994) Disruption of microfilaments in growth cones following depolarization and calcium influx. J Neurosci 14:7511-7520.

O'Brian CA, Ward NE, Liskamp RM, Bont DB. Boom JHV (1990) NMyristyl-Lys-Arg-Thr-Leu-Arg: a novel protein kinase $C$ inhihitor Biochem Pharmacol 39:49-57.

Perez F, Joliot A, Bloch-Gallego E, Zahraoui A, Triller A, Prochiant: A (1992) Antennapedia homeobox as a signal for the cellular internalization and nuclear addressing of a small exogenous peptide. $J$ Cell Sci 102:717-722.

Perez F, Lledo P-M, Karagogeos D, Vincent JD, Prochiantz A, Ayala J (1994) Rab3A and Rab3B carboxy-terminal peptides are potent and specific inhibitor of prolactin release by rat cultured anterior pituitary cells. Mol Endocrinol 8:1278-1287.

Qian J, Wang HY, Fischer I, Friedman E, Levitt P (1994) Involvement of protein kinase $\mathrm{C}$ in the axonal growth-prmoting effect on spinal cord neurons by target-derived astrocytes. J Neurobiol 25:15931612 .

Rasouly D, Rahamim E, Lester D, Matsuda Y, Lazarovici P (1992) Staurosporine-induced outgrowth in PCI 2 cells is independent of protein kinase $\mathrm{C}$ inhibition. Mol Pharmacol 42:35-43.

Robinson PJ, Sontag JM, Liu JP, Fykse EM, Slaughter C, McMahon H, Sudhof TC (1993) Dynamin GTPase regulated by protein kinase C phosphorylation in nerve terminals. Nature 365:163-166.

Sasaguri I, Kosaka C, Hirata M, Masuda J, Shimodako K, Fujishima M, Ogata J (1993) Protein kinase C-mediated inhibition of vascular smooth muscle cell proliferation: the isoforms that may mediate GI/S inhibition. Exp Cell Res 208:311-320.

Shea TB, Perrone-Bizzozero NL, Beerman ML. Benowitz LI (1991) Phospholipid-mediated delivery of anti-Gap-43 antibodies into neuroblastoma cells prevents neuritogenesis. J Neurosci 1 1:1685-1690.

Smalheiser NR (1993) Acute neurite retraction elicited by diverse agents is prevented by genistein, a tyrosine kinase inhibitor. J Neurochem $61: 340-343$.

Smith MK, Cobran RJ, Soderling TR (1990) Specificities of autoinhibitory domain peptides of four protein kinase. Implications for intact cell studies of protein kinase function. J Biol Chem 265:1837-1840.

Suidan HS, Stone SR, Hemings BA, Monard D (1992) Thrombin causes neurite retraction in neuronal cells through activation of cell surface receptors. Neuron 8:363-375.

Tanaka C. Nishizuka Y (1994) The protein kinase C family for neuronal signalling. Annu Rev Neurosci 17:551-567.

Tanaka E, Kirschner MW (1995) The role of microtubules in growth cone turning at substrate boundaries. J Cell Biol 128:127 137.

Tessier-Lavigne M (1994) Axon guidance by diffusible repellants and attractants. Curr Opinion Genet Dev 4:596-601 
Tessier-Lavigne M, Plazcek M (1991) Target attraction: are developing axons guided by chemotropism? Trends Neurosci 14:303-310.

Troy C, Derossi D, Prochiantz A, Shelanski M (1994) Efficient inhibition of SOD 1 in PC12 cells by antisense oligonucleotides linked to Antennapedia peptides. Mol Biol Cell 5:25a.
Ward NE, O'Brian CA (1993) Inhibition of protein kinase C by N-myristoylated peptide substrate analogs. Biochemistry 32:11903-11909.

Widmer F, Caroni P (1993) Phosphorylation-site mutagenesis of the growth-associated protein GAP-43 modulates its effects on cell spreading and morphology. J Cell Biol 120:503-512. 